\title{
DECISIONS AND ADMINISTRATIVE ACTS ACCORDING TO THE RENEUAL MODEL RULES ON THE EU ADMINISTRATIVE PROCEDURE AND PROPOSAL FOR REGULATION FOR AN OPEN, EFFICIENT AND INDEPENDENT EU ADMINISTRATION
}

\section{Marek Jaśkowski*}

\begin{abstract}
The author presents and analyses the notions of a decision according to ReNEUAL Model rules on EU administrative procedure and of an administrative act according to the Proposal for Regulation for an open, efficient and independent European Union administration. The discussion approaches the subsidiary character of the proposed rules and exclusions of their applicability in given cases, the designation and individual character of decisions and administrative acts, as well as their form and content. Additionally, the author considers the possibility of qualifying certain regulations as decisions or administrative acts. According to the conclusion, the scope of application of analysed proposals may turn out to be relatively restricted because of the exclusion of implementing acts in the case of the Regulation proposal and the potentially narrow interpretation of the notion of a decision in the case of the Model Rules.
\end{abstract}

* PhD in law sciences, Associate Professor at the Department of International and European Law, Faculty of Law and Administration Cardinal Stefan Wyszynski University. 


\section{Introduction}

We have been witnessing the debate concerning the uniform administrative procedure of the EU for several years now. ${ }^{1}$ Recently, important part of interest is focused on the ReNEUAL initiative ${ }^{2}$ (ReNEUAL Model Rules on EU Administrative Procedure, ${ }^{3}$ hereinafter referred to as 'Model Rules' or 'MR') and the Proposal for Regulation for an Open, Efficient and Independent European Union Administration submitted by the European Parliament.

The Model Rules are organised into six 'books': (I) the general scope of application of the model rules, their relation to sector-specific rules and a Member State's law and the definitions of wordings applied in all the books; (II) non-legislative implementation of EU law and policies by means of: rulemaking, (III) single case decision-making, (IV) contracts, (V) procedures of mutual assistance and (VI) information management. The authors emphasise, that even though the Model Rules are presented in a form adapted to their possible adoption as an EU Regulation, the project is of an academic character. The Model Rules are to provide European legal scholarship and legal practitioners with a structured framework for debating and further developing EU administrative law, and its main objective is first and foremost to develop academic ideas for improving the implementation of EU law. The following contribution is intended to constitute a part of the debate concerning Book III (single case decision-making).

1 See, inter alia: C. Harlow, Codification of EC Administrative Procedures? Fitting the Foot to the Shoe or the Shoe to the Foot?, 'European Law Journal' 1996, vol. 2, no. 1, pp. 3-25; G. A. Bermann, A Restatement of European Administrative Law: Problems and Prospects, 2009, http://www.reneual.eu/; A. Meuwese, Y. Schuurmans, and W. Voermans, Towards a European Administrative Procedure Act, 'Review of European Administrative Law' 2009, vol. 2, no. 2; J. Ziller, Alternatives in Drafting an EU Administrative Procedure Law, European Parliament 2011, http://www.europarl.europa.eu/studies.

2 J. Supernat and B. Kowalczyk (eds), Kodeks postępowania administracji Unii Europejskiej [The Code of Procedure of the EU Administration], Instytut Wydawniczy EuroPrawo, Warszawa 2017; M. Ruffert (ed.), The model rules on EU administrative procedures: adjudication, Europa Law Publishing, Groningen 2016, European administrative law series 11 .

3 Current version of the document can be found at http://reneual.eu/index.php/ projects-and-publications/reneual-1-0 [accessed 30.5.2017]. 
It is also necessary to mention the initiatives of the European Parliament on this subject. The First EP resolution was adopted on 15.1.2013. ${ }^{4}$ It requested the Commission to submit, on the basis of article 298 TFEU, a proposal for a regulation on the European Law of Administrative Procedure, following the detailed recommendations set out in the annex to the resolution. In reaction, the European Commission promised to undertake an analysis whether there were examples of maladministration resulting from gaps or weaknesses in the existing legal framework and, if so, how such instances could be most effectively avoided in the future. The Commission declared also, that it would 'consider all options to reinforce the open, efficient and independent EU administration. In doing so, the Commission [would] take full account of Parliament's recommendations. ${ }^{{ }^{5}}$ After all, the Commission did not submit a legislative proposal in the form demanded by the EP. The second attempt took place in $2016 .{ }^{6}$ This time the EP went somewhat further and presented a ready proposal of a regulation ('Proposal for a regulation of the European Parliament and of the Council for an open, efficient and independent European Union administration', hereinafter referred to as 'Regulation proposal' or 'RP'). However, this initiative was turned down by the Commission, which stated that it was 'at this stage, not convinced that the benefits of using a legislative instrument that would codify administrative law would outweigh the costs' (such as revision of a considerable volume of existing EU legislation, problems of delimitation between the general and specific rules and less flexibility). The Commission also criticised the lack of identification by the EP of the gaps and inconsistencies in current law which the proposal would allegedly aim at remedying. ${ }^{7}$ Regardless of the negative approach of the European Commission towards the proposal submitted by the European Parliament,

4 European Parliament resolution of 15.1 .2013 with recommendations to the Commission on the Law of Administrative Procedure of the European Union (2012/2024(INL)).

5 Follow up to the European Parliament resolution with recommendations to the Commission on the Law of Administrative Procedure of the European Union, adopted by the Commission on 24.4.2013 (SP(2013)251).

6 European Parliament resolution of 9.6.2016 for an open, efficient and independent European Union administration (2016/2610(RSP)).

7 Follow up to the European Parliament resolution for an open, efficient and independent European Union administration, adopted by the Commission on 4.10.2016 (SP(2016)613). 
it is worthwhile analysing the different aspect of the current proposal with a view towards future projects.

The following contribution discusses the notions of 'decision' and 'administrative act' as employed by the Model Rules and Regulation proposal, respectively. These terms are of fundamental importance, for they are one of determinants of the extent of application of both sets of rules.

\section{Designation}

\subsection{Model Rules}

The preliminary remark I would like to make is of a terminological character. The designation 'decision' is already, so to say, taken by article 288(4) TFEU, according to which: 'a decision shall be binding in its entirety. A decision which specifies those to whom it is addressed shall be binding only on them.' 'Decisions' in the meaning employed by this article encompass individual as well as general acts; what is more such a decision can have a legislative, delegated or implementing character. The choice of the same designation for an administrative decision for the purposes of codification of an administrative procedure seems confusing. Unfortunately, the present contribution may appear to be an unintended proof of that disadvantage, even though I shall do my best not to create confusion regarding the meaning of this word.

\subsection{Regulation proposal}

The proposed Regulation employs the notions of 'administrative activities' and 'administrative acts'. It should be noted that the renouncement of the designation of 'decision' is commendable for it will be helpful to avoid confusion with 'decisions' in the understanding adopted in article 288(4) TFEU. However, the Regulation proposal makes use of this form of the EU act (for instance: a decision to initiate an administrative procedure article $6 \mathrm{RP}$, procedural decisions adopted in the course of the administrative procedure - article 8(d). According to B. Adamiak, the distinction between 'decision' and 'administrative act' as understood in the proposal is as follows: 'decision' has a procedural nature, whereas 'administrative 
act' solves a case on merits. ${ }^{8}$ Nonetheless, we have to add that in certain instances the designation 'administrative act' and 'decision' seem to be used interchangeably: in chapter III ('Management of the administrative procedure') in article 9 ('Duty of careful and impartial investigation') the word 'decision' seems to be equivalent to the category of 'administrative act' (understood as an act concluding the administrative procedure). The same situation occurs in article 24(2) ('Rectification or withdrawal of administrative acts which are beneficial to a party'), which contains the expression 'lawfulness of the decision' instead of 'lawfulness of the administrative act'. Such ambiguity can create confusion and should be clarified in subsequent versions of the proposal.

'Administrative activities' are defined by article 4(b) RP as 'those carried out by the Union's administration for the implementation of Union law, with the exception of the procedures referred to Article 2(2)' (this exclusion encompasses legislative procedures, judicial proceedings and procedures leading to the adoption of non-legislative acts directly based on the Treaties, delegated acts or implementing acts). The concept of an 'administrative act' is however not explained by the proposed Regulation. According to 'The context and legal elements of a Proposal for a Regulation on the Administrative Procedure of the European Union's institutions, bodies, offices and agencies', it was omitted intentionally:

The definition of 'administrative activities' in Article 4(b) is appropriate as it gives a broad scope of application to the guarantees of good administration concretised through the Regulation. It is therefore essential not to jeopardize this goal by the definition of 'administrative act' which is indeed absent in the draft. Such a definition is very difficult to draft and any definition is prone to trigger criticisms. ${ }^{9}$

This situation is rather ambiguous. On one hand, the reasons for abandoning the attempts to define the notion of an administrative act

8 B. Adamiak, Decyzja w modelu kodeksu postępowania administracyjnego Unii Europejskiej sieci ReNEUAL i w projekcie rozporzq̨dzenia Parlamentu Europejskiego i Rady w sprawie postępowania administracyjnego instytucji, organów i jednostek organizacyjnych Unii Europejskiej [A decision in ReNEUAL Model Rules and in the Regulation Proposal of the European Parliament], [in:] Kodeks postępowania administracji Unii Europejskiej, op. cit., p. 209.

9 D.-U. Galetta et al., The context and legal elements of a Proposal for a Regulation on the Administrative Procedure of the European Union's institutions, bodies, offices and agencies. Study, European Parliament 2016, p. 18. 
outlined above are understandable. On the other hand, however, such a lack of precision leaves a great margin of discretion in the hands of the authorities applying the law (administrative, but first of all judicial ones). This, in turn, seems to contradict one of the very objectives of the codification, which is to ensure transparency and predictability.

Nevertheless, certain features of such an act can be determined by reading the content of the proposal and will be analysed below. For now, one can assume that an 'administrative act' is included in the class of 'administrative activities' (otherwise the envisaged Regulation would not be applicable to administrative acts) and it is an act which constitutes a conclusion of an administrative case (according to article 4(c), 'administrative procedure' means the process by which the Union's administration prepares, adopts, implements and enforces administrative acts'). Furthermore, B. Adamiak points out that the nature of the administrative act as an act concluding the case on merits is corroborated by the duty to state reasons (article $1 \mathrm{RP}$ ), the right to request an administrative review against administrative acts adversely affecting their rights and interests (article 20(2) RP) and the duty of notification of administrative acts (article $21 \mathrm{RP}) .{ }^{10}$ According to the same author, it can be concluded that the administrative act has an imperative character and it determines rights and obligations. It can be deducted from the definition of the term 'party' (article 4(f) of the proposed Regulation), since it defines a party as any natural or legal person whose legal position may be affected by the outcome of an administrative procedure. ${ }^{11}$

\section{Subsidiary Character}

First, however, one has to emphasise that the rule lex specialis derogat legigenerali, expressed in the Model Rules (article I-2(1)) would considerably limit the field of the effective application of the proposed solutions, for certain procedural elements are often provided for in acts constituting the basis of a decision/administrative act. This negative limitative impact can be to some extent attenuated by the principle that specific procedural rules shall be interpreted in coherence with and may be complemented by the Model Rules (article I-2(2)). What is more, the Model Rules are not intended

Ibid. 
to become a minimal standard, a deviation from which is authorised only in one direction. This is also admitted by the authors in the explanations. ${ }^{12}$ Also, the expression used in the Model Rules (article I-2(1) provides that they 'shall apply where no specific procedural rules exist'), if interpreted too generously, could be understood this to mean that the application of the Model Rules is excluded in procedures which are more or less regulated by the particular legal acts of the EU. It seems however that a different approach is intended by the authors: the Model Rules would be applicable in any procedure qualified as administrative, but the extent of the application would vary, depending of the extent of the specific regulation. The more questions remained unregulated by the specific act, the larger extent of (subsidiary) application of the Model Rules. In practice this may require the EU legislator to expressly exclude certain procedural rights in justified cases. Otherwise, such a lacuna would be filled by the Model Rules.

In the case of the Regulation proposal the situation is similar. According to article 3 thereof, the Regulation would be applicable to other legal acts of the Union providing for specific administrative procedural rules, but only without prejudice. This means that the provisions of the Regulation would not repeal or make inapplicable any other provisions inconsistent with the Regulation. This is further confirmed by the second sentence of article 3 which provides that the Regulation should only supplement such legal acts of the Union. Finally, the EU specific procedural acts should be interpreted in coherence with the relevant provisions of the Regulation. Effectively, this approach is similar to the one employed in article I- 2 of the Model Rules.

\section{Exclusion of Application to Certain Categories of Acts}

\subsection{Model Rules}

As explained above, 'decision' means administrative action addressed to one or more individualised public or private persons which is adopted unilaterally by an EU authority'. According to the authors of the Model Rules, this definition 'excludes several kinds of acts and measures', among others

12 Explanations attached to the Model Rules, p. 33. 
'it excludes (i) legislative acts which lie outside the scope of application of the model rules considered as a whole and (ii) non-legislative acts of general application which are subject to the rules established in Book II'. ${ }^{13}$ Book II would be applicable to the procedures leading to the establishment, amendment and repeal of legally binding non-legislative acts of general application, including (a) acts adopted by the Commission or the Council under Articles 290 and 291 TFEU and (b) legally binding non-legislative acts of the EU institutions, bodies, offices and agencies adopted on the basis of Treaty provisions or legislative acts. ${ }^{14}$ 'Acts of general application' are to be understood as acts of general character, as opposed to individual acts (administrative acts, acts of application of the law). ${ }^{15}$ It is therefore important to highlight the fact that not all acts adopted under article 291 TFEU are to remain in the scope of Book II. This concerns only those which are 'of general application'. Therefore, implementing measures addressed to specified persons, individuals $^{16}$ or individual Member States ${ }^{17}$ - including those adopted in comitology procedures - would fall within the ambit of Book III, and not Book II.

\subsection{Regulation proposal}

At first glance, the Regulation proposal excludes similar categories of acts to those excluded by Book III of Model Rules. There is, however,

13 Explanations, p. 95.

14 Article II-1 MR.

15 D. Dąbek, Stanowienie prawa przez unijna administrację w modelu kodeksu postępowania administracyjnego Unii Europejskiej ReNEUAL - polska perspektywa [Adopting of Legals Acts in ReNEUAL Model Rules] [in:] J. Supernat and B. Kowalczyk, op. cit., p. 174.

16 For example, decisions founded on the following provisions: article 7 of Regulation (EC) No 258/97 of the European Parliament and of the Council of 27.11.1997 concerning novel foods and novel food ingredients; article 5(8) of Regulation (EC) No. 141/2000 of the European Parliament and of the Council of 16.12 .1999 on orphan medicinal products; article 16(1) of Regulation (EU) No. 517/2014 of the European Parliament and of the Council of 16.4.2014 on fluorinated greenhouse gases and repealing Regulation (EC) No. 842/2006.

17 For example, decisions adopted on one of the following bases: annex III paragraph 2 subparagraph 3 of Council Directive of 12.12.1991 concerning the protection of waters against pollution caused by nitrates from agricultural sources (91/676/EEC); article 9 para. 4 of Council Directive 98/41/EC of 18.6.1998 on the registration of persons sailing on board passenger ships operating to or from ports of the Member States of the Community. 
an important difference between the two. While the proposed Regulation leaves out all legislative acts, non-legislative acts directly based on the Treaties, delegated acts or implementing acts, Book III of MR excludes only those of a general application. What is more, Book III does not concern acts of general application adopted on the basis of legislative acts (which are regulated by Book II), while the Regulation proposition excludes 'non-legislative acts directly based on the Treaties' (article 2(2)(c)). This leads to the conclusion, that even procedures leading to the adoption of individual implementing acts as well as individual acts adopted directly on the basis of the Treaties would escape the application of the Regulation. These far-reaching limitations are explained by the authors of 'The Context...' in the following way:

Exclusions of this kind can be justified for a project such as the one envisaged by the European Parliament predominantly in order to ensure that the sometimes confused arguments concerning the legal basis cannot be used to cast doubt on the entire project. [...] Given the potential confusion over this matter, at this phase, excluding acts under Article 291 TFEU from the scope of the Regulation will most likely allow for a higher degree of acceptability of the act and will allow to establish the codification of general principles in EU law on the basis of a limited scope of applicability of the act. ${ }^{18}$

\section{Individual and concrete character}

\subsection{Introduction}

An element which requires more detailed explanation is the individual nature of a decision (or of an administrative act), since this is the feature which allows us to distinguish them from acts of a general nature.

Firstly, the addressees of both categories of acts are designated in a different manner: general acts refer to certain categories defined on the basis of given features or situations, while individual acts specify addressees 
with regard to their identity (name) ${ }^{19}$ One should not confuse the individual designation of addressees with a situation in which the legal act defines the general qualities (and not the identity) of persons to whom it is addressed in such a way that the group of addressees is determined or determinable ex ante. The latter remains nonetheless a general act. ${ }^{20}$

It is however important to highlight the fact that not all persons individualised by an act are its addressees. An addressee is to be understood only as the person to whom the act is directed (addressed). For example, a decision or a recommendation can be addressed to a Member State. Similarly, a decision (article 288(4) TFEU) can be addressed to an individual. A regulation can be addressed to all persons having certain qualities. In such situations it is only these persons to whom the acts are directed who are their addressees. Therefore, any other persons, even if enumerated by the act, cannot be qualified as addressees. For example, a company is not an addressee of a European Commission's decision ordering the Member State to recover a state aid, because such a decision is addressed to the said Member State. Another example: a person whose assets are frozen is not an addressee of a regulation imposing such a measure, for it is addressed to financial institutions. This distinction between addressees and other persons aimed at by the act is important not just for the sake of theoretical clarity, but also for practical consequences, among others the extent of obligations of an addressee, his responsibility or procedural rights.

This phenomenon leads us to the question of naming the individual persons concerned who are not, however, the addressees of the act. Some authors prefer to use the denomination addressee anyway. For example, A. Türk refers the notion of an addressee to persons whose legal position is modified by a Union act by imposing obligation or by granting rights. At the same time, the author notes the difference between the formal addressees and persons in relation to whom the act produces immediate legal

19 W. Chróścielewski, Akt administracyjny generalny [General Administrative Act], Łódź 1994, pp. 93-95; D. Schmalz, Allgemeines Verwaltungsrecht und Grundlagen des Verwaltungsrechtsschutzes, Baden-Baden 1998, p. 218. See also the case law of the CJEU: 'A measure is of general application if it applies to objectively determined situations and produces legal effects with respect to categories of persons envisaged generally and in the abstract' (Case T-18/10, Inuit Tapiriit Kanatami and Others, Order of General Court of 6.9.2011, ECLI:EU:T:2011:419).

20 K.M. Ziemski, Indywidualny akt administracyjny jako forma działania administracji [Individual Administrative Act as the Form of Action of the Administration], Poznan 2005, p. 510. 
consequences. ${ }^{21}$ Another possibility could be borrowed from M. Goldmann, who - in relation to international instruments - uses the term 'second level addressee' defining a person who is ultimately affected by the act, as opposed to 'first level addressees' (to whom the act is explicitly addressed). The same person can be a first and a second level addressee at the same time, but not necessarily ${ }^{22}$. For the purposes of the present contribution yet another terminology will be applied: an 'addressee' for a person to whom the act is addressed and a 'targeted person' for the individualised person whose legal situation is ultimately targeted by the act.

In light of the distinction between addressees and targeted persons it is clear that certain acts can have a hybrid character: they can be addressed to general categories and at the same time target individualised persons. Regulation $881 / 2002^{23}$ could serve as an example. It established the rules concerning the freezing of resources and prohibition of making resources available to certain persons, enumerated in the annex. Such an act determines the addressees in a general way, while the target persons are individualised (e.g. 'No funds shall be made available, directly or indirectly, to, or for the benefit of, a natural or legal person, group or entity designated by the Sanctions Committee and listed in Annex I' - art. 2(2) of the regulation). ${ }^{24}$ These features of such acts have led A.G. Mengozzi to conclude (with regard to regulation 423/2007) that their nature is 'extremely hybrid': the addressees of the obligation to freeze funds are determined in a general and abstract manner and the annexes provide a detailed list of natural and legal persons whose assets are to be frozen. The annexes are therefore

21 A.H. Türk, The Concept of Legislation in European Community Law, Alphen aan den Rijn 2006, pp. 82, 86, 115, 120.

22 M. Goldmann, Inside Relative Normativity: From Sources to Standard Instruments for the Exercise of International Public Authority, 'German Law Journal' 2008, vol. 9, no. 11, p. 1886.

${ }^{23}$ Council Regulation (EC) No. 881/2002 of 27.5.2002 imposing certain specific restrictive measures directed against certain persons and entities associated with Usama bin Laden, the Al-Qaida network and the Taliban, and repealing Council Regulation (EC) No. 467/2001 prohibiting the export of certain goods and services to Afghanistan, strengthening the flight ban and extending the freeze of funds and other financial resources in respect of the Taliban of Afghanistan.

24 In the words of the CJEU, it 'lays down a prohibition, worded exceptionally broadly [...] which is addressed to whoever might actually hold the funds or economic resources in question' (Yassin Abdullah Kadi and Al Barakaat International Foundation, Cases C-402/05 P and C-415/05 P, Judgment of 3.9.2008, ECLI:EU:C:2008:461, 242-244). 
to be regarded, according to AG Mengozzi, as a set of individual decisions to include each of the persons, entities or bodies entered in those lists. ${ }^{25}$

Moreover, the individuality of a decision may also be understood as concrete (as opposed to abstract) character of a case to be resolved by such an act. ${ }^{26}$ As J. Zimmermann rightly observes, an individual (administrative) act is the result of application of law, for it is by means of such acts that an abstract and general legal rule is 'transformed' into a rule relating to a concrete situation and an individualised addressee. ${ }^{27}$ An individual act establishes legal consequences of a concrete situation, while for a general act such a situation is irrelevant. ${ }^{28}$

\subsection{Model Rules}

According to article III-2(1), a 'decision' is an 'administrative action addressed to one or more individualised public or private persons which is adopted unilaterally by an EU authority ${ }^{29}$ to determine one or more concrete cases with legally binding effect. Additionally, in the light of article I-4, a decision (as an 'administrative action') is an activity of a public authority. In turn, 'public authority' means EU authorities, ${ }^{30}$ that is 'an institution, body, office or agency of the Union'. Also other bodies are to be considered as EU authorities when they are entrusted with administrative action on behalf of the EU (according to the explanations to the MR, this may also cover Member States' authorities if they explicitly act not on their own account but 'as formal agents' on behalf of the EU). It is therefore apparent that Book III of the Model Rules resorts to the two criterions mentioned above: individual addressee and a concrete situation.

The discussed notion of a 'decision' refers then to an act, which is addressed to one or more individualised public or private persons. In the explanations, the authors clarify that it may be addressed either to a State or a group of States, or to an individual or a group of individuals, insofar

25 however, will not be analysed in the present contribution. 30 And also 'Member States' authorities; insofar as these model rules apply to them'.

BMI, Case C-548/09 P, Opinion, ECLI:EU:C:2011:735, paras. 38-41.

K.M. Ziemski, op. cit., pp. 500-501.

J. Zimmermann, Prawo administracyjne [Administrative Law], Warszawa 2010, p. 289.

K.M. Ziemski, op. cit., pp. 500-502.

'Or by a Member State authority when Article III-1(2) is applicable'. This aspect, 
as the latter is determined or can be determined ex ante. It therefore includes acts of a collective nature such as those addressed to a group of people, but excludes administrative rule-making, ${ }^{31}$ the latter understood as adopting of legally binding non-legislative acts of general application, such as delegated and implementing acts (as understood in articles 290 and 291 of TFEU), acts adopted on the basis of Treaty provisions or legislative acts (article II- 1 of MR). This also leads us to the question of delimitation between 'decisions' and 'administrative rule-making'.

The Model Rules imply that the distinction between 'decisions' and acts of rule-making lies in the individual character of the former and the general character of the latter. The fact that a 'decision' can be addressed to a group of Member States or of individuals does not contradict this distinction, as I understand it. An act addressed to a group defined generally would constitute an act of rule-making, but an act addressed to a group of persons individually enumerated would be qualified as a decision in the understanding of the Model Rules. This would be consistent with the position took by the CJUE, according to which 'the possibility of determining more or less precisely the number, or even the identity, of the persons to whom a measure applies by no means implies that it must be regarded as being of individual concern to them as long as it is established that, as in the present case, that application takes effect by virtue of an objective legal or factual situation defined by the measure in question., ${ }^{32}$ On the other hand, I believe that the decisions addressed 'to the Member States' should not be regarded as decisions as understood in the Model Rules, because effectively they do not individualise their addressees.

With regard to the problem of addressees and persons targeted by the act, the Model Rules apply a distinction between the two groups, which is apparent in the definition of a party (article III-2(3)). This term encompasses the addressees of the intended decision and other persons who are adversely affected by it and who request to be involved in the procedure. Additionally, EU sector-specific law may assign the status of party to persons not adversely affected. This formula corresponds with article 41(1)(a) of the Charter of Fundamental Rights of the European Union (CFR) which provides for the right of every person to be heard, before any individual

31 Explanations, p. 95.

32 Case C-451/98 Antillean Rice Mills NV, para. 52. It must be however emphasised that the cited judgment does not concern the very nature of the act, but only the procedural problem of locus standi of individuals according to article 263 TFEU. 
measure which would affect him or her adversely is taken. This provision does not cover the process of enacting measures of general application ${ }^{33}$. This notion of a party is wider than including only persons against whom the procedure was initiated. On the other hand, it is more restricted than the category of persons interested.

\subsection{Regulation proposal}

The notion of an administrative act is not defined by the proposal, which was left out on purpose, as we saw above. The proposed Regulation in general adopts the notion of an administrative act as an individual act, which finds confirmation in the fact that there are in chapter VI separate specific provisions concerning administrative acts of general scope (as opposed to individual acts). Also, in article 19(3) the proposed Regulation requires that 'administrative acts shall contain an individual statement of reasons relevant to the parties' situation ${ }^{34}$. The parties should also be notified in writing as soon as it is adopted and this shall take effect for a party upon notification to that party (article $21 \mathrm{RP}$ ).

The proposal does not refer to the notion of an addressee, it employs the procedural term 'party'. According to article 4(f) RP, a 'party' means any natural or legal person whose legal position may be affected by the outcome of an administrative procedure. This term seems therefore wider than the notion of an addressee. Some doubts as to the relations between these terms are however cast by recital (35) of the proposal, according to which 'parties to an administrative procedure should be able to clearly understand their rights and duties that derive from an administrative act addressed to them'. Taken literally, this might suggest that only a person to whom an administrative act is to be addressed can have the status of a party. Also article $21 \mathrm{RP}$, second sentence, which provides that 'administrative acts shall

33 Case C-221/09 AJD Tuna Ltd, Judgment of the Court of 17.3.2011, ECLI:EU:C:2011:153, para. 49.

34 One has to note, however, that according to the same provision, 'If that is not possible due to the fact that a large number of persons are concerned, a general statement of reasons shall be sufficient'. This does not necessarily contradict the individual character of an administrative act, as it can concern a group of individualised persons. This conclusion is corroborated by the next sentence in the quoted provision: 'In that case, however, any party who expressly requests an individual statement of reasons shall be provided with it'. 
take effect for a party upon notification to that party', seems to confirm that the notions of a party and that of an addressee could be assimilated.

This however seems to contradict the idea of introducing the term 'party' instead of an addressee. Furthermore, this would excessively restrict the circle of persons entitled to partake in the procedure. The rejection of such a restrictive interpretation finds confirmation in the Context..., in which it is pointed out that 'rules of administrative procedure are necessary for the realisation of the rights and interests of addressees and third parties in the implementation of EU law'. ${ }^{35}$

The reading of the proposal leads yet to another question: does the term 'a party' refer only to the persons who are to be individually affected by the outcome of the procedure? Article 4(f) RP does not include such a restriction. However, article $21 \mathrm{RP}$ provides that 'administrative acts which affect the rights and interests of the parties shall be notified in writing to them as soon as they are adopted'. What is more - it shall take effect upon notification to that party. This implies that the identity of parties should be known beforehand. This, in turn, leads to the conclusion that the category of parties encompasses only individualised persons, not general categories.

\subsection{Regulations as 'decisions' or as 'administrative acts'?}

It is important to point out that neither of the two analysed documents limits its scope of application to the formally understood notion of decisions in the meaning adopted in the Treaties (article 288 TFEU). Prima facie it seems therefore possible that the proposed rules concerning single case decision-making could be applicable not only to decisions in the meaning of article 288 TfUE, but also to other sources of EU law. The present contribution is not conceived as an attempt to exhaustively analyse all the possible categories of acts belonging to the EU legal system as 'simplified' by the Lisbon Treaty. Nevertheless, it seems interesting to discuss at least certain examples of regulations.

As indicated above, both Book III of the Model Rules and the Regulation proposal exclude applicability to the legislative procedures, and therefore the legislative acts can be set aside right away. As for other legal acts, one has to remember that not all acts adopted under article 291 TFEU are excluded from the scope of Book III of the Model Rules, for the exclusion would concern only 
those which are 'of general application'. Therefore, implementing measures addressed to specified persons, individuals or individual Member States would fall within the ambit of Book III, and not Book II of Model Rules.

Both Book III of the Model Rules and the Regulation proposal ${ }^{36}$ are not applicable to procedures leading to adopting acts of general application. Does this mean that they do not cover adopting the regulations, which ex definitione are acts of general application (article 288(2) TFEU)? This problem is surprisingly absent in Book III MR and its explanations. I find it surprising for the following reason. First of all, MR construes its own definition of a decision, autonomous from the one defined in the Treaties. Similarly, the Regulation proposal uses the undefined (by the EU law) notion of an administrative act. All this must have provoked questions as to the limits of these terms, including questions concerning the relations between those terms and regulations. Even more so, that the idea that regulations may constitute the final result of an administrative procedure and - what is more - that they could be regarded as 'decisions' - is present in the literature. ${ }^{37}$ Qualifying the anti-dumping regulations, or at least some parts of them, as 'collective decisions' was neither unknown to the case law of the Court of Justice. ${ }^{38}$

Let us consider whether a regulation could be recognised as a decision in the light of the Model Rules. First of all, there is the problem of acts of a hybrid nature (discussed above), which define the addressees in a general manner, but at the same time do affect legal situation of targeted individuals. Such targeted persons would not be addressees of hybrid acts, but they could be qualified as 'other persons who are adversely affected by it' (article III-2(3) MR). Would this entitle them to be granted the status of a party to the proceedings? Probably not, because an act defining its addressees in a general way would be qualified as an act of general application and therefore Book II of the Model Rules would be applicable, and not Book III. ${ }^{39}$ In other words, it would not be an 'administrative action addressed to

36 With the exception of chapter VI.

37 See, with regard to anti-dumping regulations: A.H. Türk, op. cit., pp. 137-138; H.C.H. Hofmann, Seven Challenges for EU Administrative Law, 'Review of European Administrative Law' 2009, vol. 2, no. 2, p. 39.

38 NTN Toyo Bearing Company Ltd, Case 113/77, Judgment of 29.3.1979, ECLI:EU:C:1979:91, paras 11-12.

39 According to the authors of the Model Rules, 'Article III-2(1) excludes several kinds of acts and measures. It excludes [...] (ii) non-legislative acts of general application which are subject to the rules established in Book II' (Explanations, p. 95). 
one or more individualised public or private persons' (article III-2(1) MR), since the regulation would only target individual persons, but would not be addressed to them. Let us look at Council Regulation (EU) 269/2014 of 17.3.2014 concerning restrictive measures in respect to actions undermining or threatening the territorial integrity, sovereignty and independence of Ukraine, as an example. It does not specify an individual addressee, imposing the freezing of funds and prohibition of making available any funds or economic resources. These obligations are addressed to all persons within generous limits referred to in article 17 of the said regulation (it is applicable within the territory of the Union, including its airspace; on board any aircraft or any vessel under the jurisdiction of a Member State; to any person inside or outside the territory of the Union who is a national of a Member State; to any legal person, entity or body, inside or outside the territory of the Union, which is incorporated or constituted under the law of a Member State; to any legal person, entity or body in respect of any business undertaken in whole or in part within the Union). At the same time, the regulation targets natural persons 'identified by the Council as being responsible for actions which undermine or threaten the territorial integrity, sovereignty and independence of Ukraine, and natural or legal persons, entities or bodies associated with them'. They are not, however, addressees of the regulation. Consequently, the same is true with regard to implementing regulations adopted by the Council due to modify the list of persons targeted.

A similar problem occurs in the case of the previously mentioned regulations imposing anti-dumping duties, because - technically speaking - they do not individualise their addressees, only targeted exporting producers. The situation is similar, or even more ambiguous in the case of regulations withdrawing the acceptance of the undertaking for individualised exporting producers (on the basis of article 8 of regulation 2016/1036). When a producer wishes to withdraw from the undertaking, the Commission withdraws the undertaking in this individual case. Still, as it is undertaken in a form of a regulation which has a generally defined addressee (customs authorities), they do not seem to fit in the notion of a decision according to Book III of the Model Rules.

Yet another example of a regulation of a character close to a decision is an implementing regulation issued on the basis of regulation $1831 / 2003$. $^{40}$

40 Regulation (EC) No. 1831/2003 of the European Parliament and of the Council of 22.9.2003 on additives for use in animal nutrition. 
This act provides that, having regard to an application submitted by any person seeking authorisation for a feed additive, and to the scientific opinion delivered with regard to such an application, the authorisation may be granted to an applicant ('holder of the authorisation') by the Commission in the form of a regulation. It may be not irrelevant that in such a case the holder of the authorisation is even specified in the title of such a regulation. ${ }^{41}$ This act could be actually assimilated to a decision, but I do insist that the literally interpreted requirement of an individual addressee in article III-2(1) MR is an obstacle, or an argument against such an conclusion (or at least it creates some confusion as to this possibility).

As for the Regulation proposal, on the one hand, thanks to the fact that the notions of an administrative act and of administrative activities as used in the Regulation procedure is not as rigid as the concept of a decision in Book III of the Model Rules, it seems possible, under certain conditions, to qualify a regulation as an administrative act. On the other hand, the range of possibilities is greatly reduced due to the exclusion of all implementing acts, regardless of their features, as well as non-legislative acts directly based on the Treaties. This excludes, apparently, all the examples of regulations discussed in preceding paragraphs (implementing regulations modifying lists of targeted persons, implementing antidumping regulations, implementing regulations authorising the use of a given food additive).

\section{Form and Content}

\subsection{Model Rules}

A decision can be issued in writing or in electronic form, unless specific provisions provide otherwise. It should be signed (with a qualified signature for electronic forms) and specify the issuing authority. The language of the decision is that chosen by the addressee, provided that it is one of the official languages of the EU.

41 See, for example, Commission Implementing Regulation (EU) 2017/895 of 24.5.2017 concerning the authorisation of a preparation of 3-phytase produced by Komagataella pastoris (CECT 13094) as a feed additive for chickens for fattening and egg-laying hens (holder of authorisation Fertinagro Nutrientes S.L.). 
Article III-28 contains the imperative that a decision be clearly specified in order to enable the parties to understand their rights or duties. Similarly, the reasons, which constitute the indispensable element of the decision, should be expressed in a clear, simple and understandable manner. In fact, the statement of reasons is addressed to two kinds of persons and its role is twofold: firstly, to enable the person concerned to learn the motives of the authority which adopted the act and to take the decision to initiate (or not) an action against it before the CJEU. Secondly, the statement of reasons is addressed to the Court and it should enable it to exercise the judicial review of the contested act. This is derived from the case-law of the CJEU ${ }^{42}$ and it is also expressed in article III-29 MR. This could be supplemented by yet another addressee of the statement of reasons, which in certain procedures would be the administrative authority superior to the one which issued the decision and which - in the case of an administrative appeal - should evaluate the correctness of the decision in the light of the statement of reasons. Additionally, article III-30 provides that the decision should indicate the possibility of an administrative appeal (where available), of judicial action and their time limits. It should also contain information concerning recourse to the Ombudsman. It should be noted that article III-30 requires that the said information be provided to the addressee of the act, not taking account the interests of other persons concerned (e.g. targeted persons).

It should be observed that the obligation to state the reasons of the act is expressed also in the $\mathrm{CFR}^{43}$ and in the Treaty itself. ${ }^{44}$ Requirement of a signature as an essential element ${ }^{45}$ as well as the obligation to formulate the content of the act in a clear and understandable way are in turn enshrined in the case law of the CJ as a corollary of the principle of legal certainty. ${ }^{46}$ In this sense the Model Rules do not really seem to add a great deal to the existing legal obligations of the authorities. On the other hand, the duty to indicate available remedies de lege lata does not have its legal basis. To this extent the Model Rules add another guarantee for the addressee.

42 Yassin Abdullah Kadi and Al Barakaat International Foundation, Cases C-402/05 P and C-415/05 P, Judgment of 3.9.2008, ECLI:EU:C:2008:461, para. 336-337, 349.

43 Article 41(2)(c) CFR.

44 Article 296(2) TFEU.

45 BASF and others, Case C-137/92 P, Judgment of 15.6.1994, ECLI:EU:C:1994:247, paras 76-78.

46 Stichting ROM-projecten, Case C-158/06, Judgment of 21.6.2007, ECLI:EU:C:2007:370, para. 25. 


\subsection{Regulation proposal}

According to article $18 \mathrm{RP}$, 'administrative acts shall be in writing and shall be signed by the competent authority. They shall be drafted in a clear, simple and understandable manner.' With regard to the duty to state reasons, the Regulation proposal is more specific than the Model Rules. It requires not only that the reasons shall be stated 'clearly', but it also specifies certain elements to be included in the statement of reasons (the legal basis, the relevant facts and the way in which the different relevant interests have been taken into account). Additionally, the statement of reasons should be individually suited to the parties' situation. Even though in cases of a large number of persons concerned it can have a general character, any party who expressly requests an individual statement of reasons should be provided with it.

An important innovation derives from article 20 RP. Not only does this provision impose an obligation to inform the relevant persons that the administrative review is possible, but - first of all - it introduces the rule, according to which the parties shall have the right to request an administrative review against administrative acts adversely affecting their rights and interests. Such requests for administrative reviews are to be submitted to the hierarchical superior authority or, where that is not possible, to the same authority which adopted the administrative act. If no request is submitted within the time limit, the administrative act shall be deemed final. According to recital (34), the request for administrative review would not impede access to judicial review: an administrative act is to be considered final if the party does not submit a request for administrative review within the time limit or, if the party submits such a request, the final administrative act is the act which concludes that administrative review'. Finally, according to article 20(4) RP, administrative acts shall clearly refer, where Union law so provides, to the possibility of bringing judicial proceedings or lodging a complaint with the European Ombudsman.

It should be observed that, having regard to the fundamental character of the innovation providing for the right to administrative review, thid seems incomplete. The Regulation proposal does not make precise the procedural aspect of this right, nor does it determine the time limits for calling for an administrative appeal. This information is to be included in the administrative act itself. Furthermore, as it is rightly pointed out in the Context..., 
'such regulation of administrative review should in any case address the particularities of review of the decisions adopted by Union's agencies, and it should make clear that requesting administrative review is not a prerequisite for bringing an action before the CJEU'. ${ }^{47}$

Surprisingly, this important innovation is not addressed in the Explanatory Memorandum ${ }^{48}$ attached to the Regulation proposal.

\section{Conclusion}

On the basis of the limited analysis presented here, it is submitted that the scope of application of analysed documents may seem to be more restricted then initially expected, although for different reasons. In the case of the Regulation proposal, the notion of an administrative act is not defined, which would enable one to encompass by it a wider category of acts, then in the case of a 'decision' as understood in Book III of the Model Rules. On the other hand, the exclusion of implementing acts by the Regulation proposal is susceptible to considerably limit its significance in certain areas. This is apparently intended by the authors, who wanted to ensure that the proposal does not exceed the limits imposed by the proposed legal basis (article 298 TFEU). ${ }^{49}$ The Model Rules, in turn, define the notion of a 'decision', but I submit that it is this definition which may significantly limit the scope of application of Book III of the MR. If the requirement that the 'decision' has to be addressed to individualised persons, is interpreted literally, it would constitute a major obstacle to applying Book III of the Model Rules in procedures leading to the adoption of regulations. This might very well be intended, but why then should one bother with construing a specific definition of a decision, instead of referring to the notion of 'decisions specifying an addressee' according to article 288 TFUE? At the same time, it would be something of a disappointment because of a missed opportunity. Another possible explanation is that the notion of an act 'addressed' to an individualised person should encompass not only those, to whom it is addressed, but also those, who are targeted in an individual

47 D.-U. Galetta et al., op. cit., p. 30.

48 http://www.europarl.europa.eu/meetdocs/2014_2019/plmrep/COMMITTEES/ JURI/DV/2016/01-28/1083272EN.pdf [accessed 30.5.2017]

49 D.-U. Galetta et al., op. cit., p. 16. 
manner by such an act. This is not impossible,${ }^{50}$ but such an approach does not seem commendable. Firstly, it would stretch the notion of an addressee beyond literal limits. Secondly, defining the term 'party' article III-2(3) distinguishes between addressees and other parties concerned by the act. This leads to the conclusion that the assimilation of addressees and targeted persons is not intended by Book III of the Model Rules.

As regards the designations employed by the analysed proposals, the choice of an 'administrative act' seems more convenient, because a 'decision' is a term already in use in EU law, which is susceptible to create confusion. The notion of an 'administrative act' remains however undefined. This may have certain advantages, as pointed out above, but this flexibility comes at a price: the effective extent of protection resulting from the Regulation will only be seen in practice, for the absence of definition leaves an important margin of discretion to the authorities (even if judicial). This is not what would be expected of an act which is supposed to ensure predictability.

\section{Bibliography}

1. Adamiak B., Decyzja w modelu kodeksu postępowania administracyjnego Unii Europejskiej sieci ReNEUAL i w projekcie rozporzadzenia Parlamentu Europejskiego i Rady w sprawie postępowania administracyjnego instytucji, organów i jednostek organizacyjnych Unii Europejskiej, [in:] J. Supernat and B. Kowalczyk (eds.), 'Kodeks postępowania administracji Unii Europejskiej', Warszawa 2017.

2. Bermann G.A., A Restatement of European Administrative Law: Problems and Prospects, 2009, http://www.reneual.eu/.

3. Chróścielewski W., Akt administracyjny generalny, Łódź 1994.

4. Dąbek D., Stanowienie prawa przez unijnq administrację $w$ modelu kodeksu postępowania administracyjnego Unii Europejskiej ReNEUAL - polska perspektywa, [in:] J. Supernat and B. Kowalczyk (eds.), 'Kodeks postępowania administracji Unii Europejskiej’, Warszawa 2017.

5. Galetta D.-U., Hofmann H.C.H., Mir-Puigpelat O., and Ziller J., The context and legal elements of a Proposal for a Regulation on the Administrative Procedure of the European Union's institutions, bodies, offices and agencies. Study, European Parliament 2016.

50 See NTN Toyo Bearing Company Ltd, Case 113/77, Judgment of 29.3.1979, ECLI:EU:C:1979:91, paras. 11-12. 
6. Goldmann M., Inside Relative Normativity: From Sources to Standard Instruments for the Exercise of International Public Authority, 'German Law Journal' 2008, vol. 9, no. 11.

7. Harlow C., Codification of EC Administrative Procedures? Fitting the Foot to the Shoe or the Shoe to the Foot?, 'European Law Journal' 1996, vol. 2, no. 1, pp. 3-25.

8. Hofmann H.C.H., Seven Challenges for EU Administrative Law, 'Review of European Administrative Law' 2009, vol. 2, no 2.

9. Meuwese A., Schuurmans Y., and Voermans W., Towards a European Administrative Procedure Act, 'Review of European Administrative Law' 2009, vol. 2, no. 2.

10. Ruffert M., The model rules on EU administrative procedures: adjudication, Europa Law Publishing, Groningen 2016, European administrative law series 11.

11. Schmalz D., Allgemeines Verwaltungsrecht und Grundlagen des Verwaltungsrechtsschutzes, Baden-Baden 1998.

12. Supernat J., and Kowalczyk B., Kodeks postępowania administracji Unii Europejskiej, Instytut Wydawniczy EuroPrawo, Warszawa 2017.

13. Türk A.H., The Concept of Legislation in European Community Law, Alphen aan den Rijn 2006.

14. Ziemski K.M., Indywidualny akt administracyjny jako forma działania administracji, Poznań 2005.

15. Ziller J., Alternatives in Drafting an EU Administrative Procedure Law, European Parliament 2011, http://www.europarl.europa.eu/studies.

16. Zimmermann J., Prawo administracyjne, Warszawa 2010. 